\title{
Energy Balance Calculation with Life Cycle Assessment for Production of Palm Biodiesel in Indonesia
}

\author{
Yoyon Wahyono ${ }^{1}, H$. Hadiyanto ${ }^{1, *}$, Mochamad Arief Budihardjo ${ }^{1}$, and Widayat ${ }^{2}$ \\ ${ }^{1}$ Master Program of Environmental Science, School of Postgraduate Studies, Diponegoro University, Semarang - Indonesia \\ ${ }^{2}$ Department of Chemical Engineering, Faculty of Engineering, Diponegoro University, Semarang - Indonesia
}

\begin{abstract}
Energy balance analysis study for the production process of biodiesel needs to be done to find out whether a production process of biodiesel activity has a surplus energy or minus energy. This study aims to analyse the balance of energy of the plantation of palm, production of palm oil, and production process units of biodiesel with the life cycle assessment in Banyuasin - Indonesia. The results of this study indicate that the largest energy input in the plantation of palm, production of palm oil, and production process units of biodiesel sequentially is the use of urea as N-fertilizer, electricity, and methanol. The value of NEB and NER in the production process of palm biodiesel sequentially is $5871 \mathrm{MJ}$ and 1.17 . Finally, the production process of palm biodiesel in Banyuasin area has a positive energy balance. The activity of production of palm biodiesel is proper to operate because it produces an energy surplus.
\end{abstract}

Keywords: Biodiesel; Energy Balance; Life Cycle Assessment.

\section{Introduction}

Biodiesel is an alternative solution for the availability of renewable bioenergy which can be used as a substitute for diesel energy. Biodiesel has the benefit of being more environmentally friendly than diesel. Palm oil is the raw material for producing biodiesel. Many studies on the Life Cycle Assessment (LCA) of the biodiesel production process, objective to calculate the environmental pollution potential impact from the biodiesel production process $[1,2,3,4,5]$.

In addition to studies to analyse the potential impact of environmental pollution, the study of energy balance analysis of the biodiesel production process needs to be done. Analysis of energy balance is to calculate the value of Net Energy Balance (NEB) and Net Energy Ratio (NER). NEB is calculated utilizing output energy minus input energy of the biodiesel production process. NER is calculated utilizing output energy divided by input energy of the biodiesel production process. The calculation of NEB and NER can be positive $(+)$ or negative (-). The indicator of success for the study of energy balance analysis so that the biodiesel production process is proper to be operated is NEB and NER are positive $[6,7,8]$.

In Indonesia, several studies on energy balance analysis in the production process of palm biodiesel have been carried out by [9] and [10]. Research [9] analyzed energy balance for production of palm biodiesel A in Sumatra and production of palm biodiesel $\mathrm{B}$ in Kalimantan. The results of this study report the value of energy balance of production of palm biodiesel A and production of palm biodiesel B is positive. Research [10] analyzed energy consumption for production of palm biodiesel in Banten.

Energy analysis can be calculated with the LCA. In ISO 14040 contains the LCA standard. Scope definition, analysis of inventory, and assessment of impact are the LCA phase based on ISO 14040 [2]. Analysis of LCA can be done using SimaPro and openLCA software $[15,16$, 17].

The renewal of this study is first, analyzing energy balance for plantation of palm, production of palm oil, production of biodiesel in a different area of the study [9] and [10]. Second, energy inputs can be detailed in 5 categories of energy sources, namely water renewable, wind, biomass un-renewable, biomass renewable, fossils un-renewable, diesel, nuclear un-renewable, and geothermal renewable. Research [9] and [10] only lists total energy requirements without details of the energy source category.

This study aims to analysis energy balance for plantation of palm, production of palm oil, production of biodiesel with LCA method in Banyuasin - Indonesia. The current study utilizes the Cumulative Energy Demand (CED) as a method of impact assessment for the production process of palm biodiesel. CED shows the results of energy demand in 5 categories of energy sources, namely water renewable, wind, biomass unrenewable, biomass renewable, fossils un-renewable, diesel, nuclear un-renewable, and geothermal renewable [11].

Corresponding author: hadiyanto@live.undip.ac.id 


\section{Research Methods}

\subsection{Definition of Scope}

The unit of function in this study is 1 ton of biodiesel. Figure 1 show system boundary of the production of palm biodiesel.

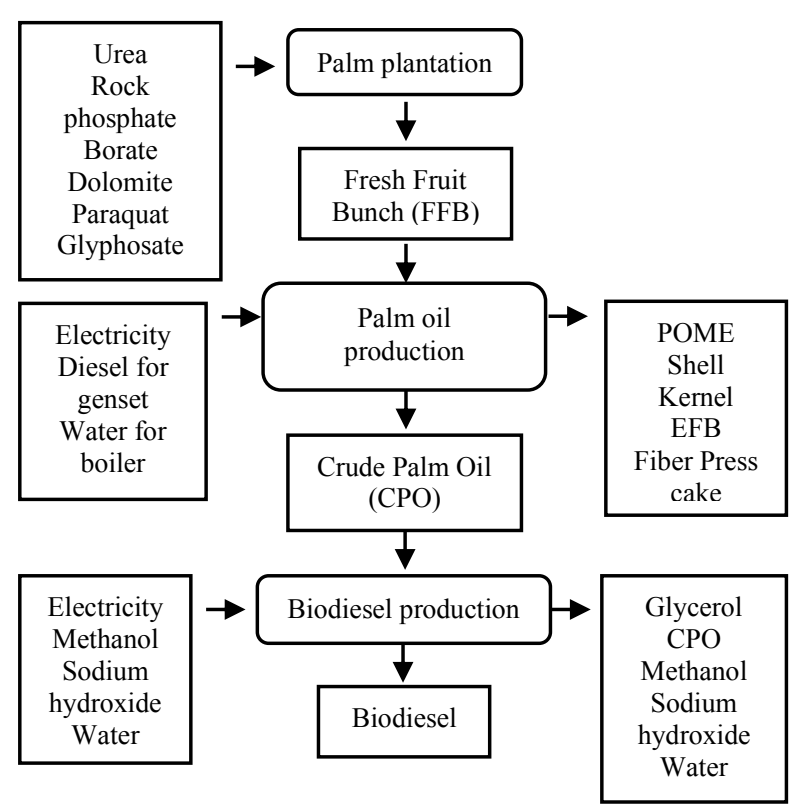

Fig. 1. System boundary of the production of palm biodiesel

\subsection{Inventory Data}

The data of inventory from data of secondary on palm biodiesel production in Banyuasin - Indonesia [12]. This study utilizes the faculty version of SimaPro 8.4.0.0 software and utilizes Ecoinvent 3 database. Table 1, Table 2, and Table 3 show data of inventory of plantation of palm, production of palm oil, production of biodiesel.

Table 1. Palm Plantation Process Unit Inventory Data

\begin{tabular}{|c|c|c|c|}
\hline Data & Units & Inputs & Outputs \\
\hline Urea & Ton & 0.10437 & \\
\hline Rock Phosphate & Ton & 0.10973 & \\
\hline Borate & Ton & 0.01048 & \\
\hline Dolomite & Ton & 0.09792 & \\
\hline Paraquat & Ton & 0.0023 & \\
\hline Glyphosate & Ton & 0.003 & \\
\hline FFB & Ton & & 6.084 \\
\hline
\end{tabular}

Table 2. Palm Oil Production Process Unit Inventory Data

\begin{tabular}{|c|c|c|c|}
\hline Data & Units & Inputs & Outputs \\
\hline FFB & Ton & 6.084 & \\
\hline Electricity & $\mathrm{kWh}$ & 95.81 & \\
\hline Diesel for genset & Ton & 0.004067 & \\
\hline Water for boiler & Ton & 5.75 & \\
\hline POME & Ton & & 0.274 \\
\hline Shell & Ton & & 0.22 \\
\hline Kernel & Ton & & 0.35 \\
\hline
\end{tabular}

\begin{tabular}{|c|c|c|c|}
\hline EFB & Ton & & 1.47 \\
\hline Fiber & Ton & & 0.83 \\
\hline Press cake & Ton & & 1.66 \\
\hline CPO & Ton & & 1.28 \\
\hline
\end{tabular}

Table 3. Biodiesel Production Process Unit Inventory Data

\begin{tabular}{|c|c|c|c|}
\hline Data & Units & Inputs & Outputs \\
\hline CPO & Ton & 1.28 & \\
\hline Electricity & $\mathrm{kWh}$ & 256.5 & \\
\hline Methanol & Ton & 0.64 & \\
\hline Sodium hydroxide & Ton & 0.029 & \\
\hline Water & Ton & 1.5 & \\
\hline Biodiesel & Ton & & 1 \\
\hline Glycerol & Ton & & 0.22 \\
\hline CPO & Ton & & 0.19 \\
\hline Methanol & Ton & & 0.51 \\
\hline Sodium hydroxide & Ton & & 0.029 \\
\hline Water & Ton & & 1.5 \\
\hline
\end{tabular}

\subsection{Impact Assessment}

The current study utilizes the CED as a method of LCA for the production process of palm biodiesel. CED shows the results of energy demand in 5 categories of energy sources, namely water renewable, wind, biomass unrenewable, biomass renewable, fossils un-renewable, diesel, nuclear un-renewable, and geothermal renewable [11]. The following table 4 is the method of CED impact assessment implemented in Ecoinvent.

Table 4. CED impact assessment method

\begin{tabular}{|c|c|c|}
\hline Categories & Sub Categories & Includes \\
\hline \multirow[t]{3}{*}{$\begin{array}{l}\text { Un-renewable } \\
\text { resources }\end{array}$} & Forests of primer & $\begin{array}{lr}\text { Biomass and } \\
\text { wood from } \\
\text { forests of primer }\end{array}$ \\
\hline & Fossil & $\begin{array}{l}\text { Natural gas, } \\
\text { lignite, peat, } \\
\text { coal mining off- } \\
\text { gas, hard coal, } \\
\text { crude oil }\end{array}$ \\
\hline & Nuclear & Uranium \\
\hline \multirow[t]{5}{*}{$\begin{array}{l}\text { Renewable } \\
\text { Resources }\end{array}$} & Solar & $\begin{array}{lr}\text { Energy of solar } \\
\text { (used } \\
\text { electricity } \\
\text { heat) }\end{array}$ \\
\hline & Biomass & $\begin{array}{l}\text { Wood, products } \\
\text { of food, } \\
\text { agriculture } \\
\text { biomass, straw }\end{array}$ \\
\hline & Wind & Energy of wind \\
\hline & Geothermal & $\begin{array}{l}\begin{array}{l}\text { Energy } \\
\text { geothermal } \\
\text { (shallow: }\end{array} \\
\text { 300m) }\end{array}$ \\
\hline & Water & $\begin{array}{l}\text { Hydro power of } \\
\text { reservoir, Run } \\
\text { of hydro power } \\
\text { of river }\end{array}$ \\
\hline
\end{tabular}




\subsection{Interpretation}

Each processing unit of plantation of palm, production of palm oil, production of biodiesel has a different energy balance depending on the energy input and mass input in part process.

\section{Results and Discussions}

\subsection{Energy input of Production of Palm Biodiesel}

In Table $5 \mathrm{~A}$, the results of energy input calculations on the palm plantation process unit, the use of urea as Nfertilizer has the largest value of energy input, namely in the un-renewable fossil energy category of $6170 \mathrm{MJ}$. This is caused by the production of urea as $\mathrm{N}$-fertilizer using large amounts of un-renewable fossil energy sources. This energy of input value is greater than energy of input calculated in the study [9], [13], [15], [16], and [17]. The value of input energy using the $\mathrm{N}$-fertilizer in research [9], [13], [15], [16], and [17] in the palm plantation process unit is $2900 \mathrm{MJ}, 2338 \mathrm{MJ}, 2790 \mathrm{MJ}$, $5900 \mathrm{MJ}$, and $5290 \mathrm{MJ}$. This energy of input value is smaller than energy of input calculated in the study [14] and [18]. The value of input energy using the $\mathrm{N}$-fertilizer in research [14] and [18] in the palm plantation process unit is $7610 \mathrm{MJ}$ and $6490 \mathrm{MJ}$.

The total input energy in the palm plantation process unit is the total input energy using urea as $\mathrm{N}$-fertilizer, phosphate rock, borax, dolomite, paraquat, and glyphosate by summing the categories of water renewable, wind, biomass un-renewable, biomass renewable, fossils un-renewable, diesel, nuclear unrenewable, and geothermal renewable is $8007 \mathrm{MJ}$. The total input energy in the palm plantation process unit is greater than the total energy input in the palm plantation process unit in research [9], [13], and [17]. The total value of input energy in the palm plantation process unit in the study [9], [13], and [17] is $7080 \mathrm{MJ}, 2741 \mathrm{MJ}$, and 6460 MJ. The total input energy in the palm plantation process unit is smaller than the total energy input in the palm plantation process unit in research [14], [15], [16], [18]. The total value of input energy in the palm plantation process unit in the study [14], [15], [16], and [18] is $9450 \mathrm{M}, 8750 \mathrm{MJ}, 9520 \mathrm{MJ}$, and $9260 \mathrm{MJ}$.

Table 5. Energy input of Production of Palm Biodiesel

\begin{tabular}{|c|c|c|c|c|c|c|}
\hline \multicolumn{7}{|c|}{ A. Energy input of palm plantation process unit } \\
\hline $\begin{array}{l}\text { Pal } \\
\text { m } \\
\text { pla } \\
\text { ntat } \\
\text { ion }\end{array}$ & $\begin{array}{l}\text { Fossi } \\
\text { l un- } \\
\text { rene } \\
\text { wabl } \\
\text { e }\end{array}$ & $\begin{array}{l}\text { Nucl } \\
\text { ear } \\
\text { un- } \\
\text { rene } \\
\text { wabl } \\
\text { e }\end{array}$ & $\begin{array}{l}\text { Biom } \\
\text { ass } \\
\text { un- } \\
\text { renew } \\
\text { able }\end{array}$ & $\begin{array}{l}\text { Biom } \\
\text { ass } \\
\text { renew } \\
\text { able }\end{array}$ & $\begin{array}{l}\text { Wind, } \\
\text { solar, } \\
\text { geothe } \\
\text { rmal } \\
\text { renew } \\
\text { able }\end{array}$ & $\begin{array}{l}\text { Wat } \\
\text { er } \\
\text { rene } \\
\text { wabl } \\
\text { e }\end{array}$ \\
\hline $\begin{array}{l}\text { Ure } \\
\text { a as } \\
\mathrm{N}\end{array}$ & 6170 & 149 & 0.2 & 52.1 & 9.51 & 67.4 \\
\hline
\end{tabular}

\begin{tabular}{|c|c|c|c|c|c|c|}
\hline $\begin{array}{l}\text { Pal } \\
\text { m } \\
\text { oil } \\
\text { pro } \\
\text { duc } \\
\text { tion }\end{array}$ & $\begin{array}{l}\text { Fossi } \\
\text { l un- } \\
\text { rene } \\
\text { wabl } \\
\text { e }\end{array}$ & $\begin{array}{l}\text { Nucl } \\
\text { ear } \\
\text { un- } \\
\text { rene } \\
\text { wabl } \\
\text { e }\end{array}$ & $\begin{array}{l}\text { Biom } \\
\text { ass } \\
\text { un- } \\
\text { renew } \\
\text { able }\end{array}$ & $\begin{array}{l}\text { Biomas } \\
\text { s } \\
\text { renewa } \\
\text { ble }\end{array}$ & $\begin{array}{l}\text { Wind, } \\
\text { solar, } \\
\text { geothe } \\
\text { rmal } \\
\text { renew } \\
\text { able }\end{array}$ & $\begin{array}{l}\text { Wat } \\
\text { er } \\
\text { rene } \\
\text { wab } \\
\text { le }\end{array}$ \\
\hline $\begin{array}{l}\text { Pho } \\
\text { sph } \\
\text { ate } \\
\text { rock }\end{array}$ & 128 & 3.74 & 0 & 0.00381 & 0.181 & 0.57 \\
\hline $\begin{array}{l}\text { Bor } \\
\text { ax }\end{array}$ & 224 & 15 & $\begin{array}{r}0.025 \\
6 \\
\end{array}$ & 3.32 & 1.17 & 8.3 \\
\hline $\begin{array}{l}\text { Dol } \\
\text { omi } \\
\text { te }\end{array}$ & 49.3 & 7.71 & $\begin{array}{r}0.008 \\
18\end{array}$ & 2.35 & 0.519 & 2.48 \\
\hline $\begin{array}{l}\text { Para } \\
\text { quat }\end{array}$ & 353 & 141 & 0 & 0.00226 & 7.03 & 17.4 \\
\hline $\begin{array}{l}\text { Gly } \\
\text { pho } \\
\text { sate }\end{array}$ & 489 & 62.1 & 0.119 & 15.3 & 4.28 & 22.8 \\
\hline Ein & 8007 & & & & & \\
\hline
\end{tabular}

B. Energy input of palm oil production process unit

\begin{tabular}{|c|c|c|c|c|c|c|}
\hline $\begin{array}{l}\text { Pal } \\
\text { m } \\
\text { oil } \\
\text { pro } \\
\text { duc } \\
\text { tion }\end{array}$ & $\begin{array}{l}\text { Fossi } \\
\text { l un- } \\
\text { rene } \\
\text { wabl } \\
\text { e }\end{array}$ & $\begin{array}{l}\text { Nucl } \\
\text { ear } \\
\text { un- } \\
\text { rene } \\
\text { wabl } \\
\text { e }\end{array}$ & $\begin{array}{l}\text { Biom } \\
\text { ass } \\
\text { un- } \\
\text { renew } \\
\text { able }\end{array}$ & $\begin{array}{l}\text { Biomas } \\
\text { s } \\
\text { renewa } \\
\text { ble }\end{array}$ & $\begin{array}{l}\text { Wind, } \\
\text { solar, } \\
\text { geothe } \\
\text { rmal } \\
\text { renew } \\
\text { able }\end{array}$ & $\begin{array}{l}\text { Wat } \\
\text { er } \\
\text { rene } \\
\text { wab } \\
\text { le }\end{array}$ \\
\hline $\begin{array}{l}\begin{array}{l}\text { Die } \\
\text { sel }\end{array} \\
\end{array}$ & 231 & 1.13 & $\begin{array}{r}0.001 \\
65 \\
\end{array}$ & 0.231 & 0.0656 & 0.41 \\
\hline $\begin{array}{l}\text { Wat } \\
\text { er }\end{array}$ & 0.452 & $\begin{array}{r}0.035 \\
3 \\
\end{array}$ & $\begin{array}{r}0.000 \\
0426 \\
\end{array}$ & 0.00904 & $\begin{array}{r}0.0019 \\
8 \\
\end{array}$ & $\begin{array}{r}0.02 \\
16 \\
\end{array}$ \\
\hline $\begin{array}{l}\text { Elec } \\
\text { trici } \\
\text { ty } \\
\end{array}$ & 1040 & 5.81 & $\begin{array}{r}0.009 \\
82 \\
\end{array}$ & 1.62 & 2.59 & 97 \\
\hline Ein & 1380 & & & & & \\
\hline
\end{tabular}

C. Energy input of biodiesel production process unit

\begin{tabular}{|c|c|c|c|c|c|c|}
\hline $\begin{array}{l}\text { Bio } \\
\text { dies } \\
\text { el } \\
\text { pro } \\
\text { duc } \\
\text { tion }\end{array}$ & $\begin{array}{l}\text { Fossi } \\
\text { l un- } \\
\text { rene } \\
\text { wabl } \\
\text { e }\end{array}$ & $\begin{array}{l}\text { Nucl } \\
\text { ear } \\
\text { un- } \\
\text { rene } \\
\text { wabl } \\
\text { e }\end{array}$ & $\begin{array}{l}\text { Biom } \\
\text { ass } \\
\text { un- } \\
\text { renew } \\
\text { able }\end{array}$ & $\begin{array}{l}\text { Biomas } \\
\text { s } \\
\text { renewa } \\
\text { ble }\end{array}$ & $\begin{array}{l}\text { Wind, } \\
\text { solar, } \\
\text { geothe } \\
\text { rmal } \\
\text { renew } \\
\text { able }\end{array}$ & $\begin{array}{l}\text { Wat } \\
\text { er } \\
\text { rene } \\
\text { wab } \\
\text { le }\end{array}$ \\
\hline $\begin{array}{l}\text { Met } \\
\text { han } \\
\text { ol }\end{array}$ & $\begin{array}{r}2100 \\
0 \\
\end{array}$ & 190 & 0.232 & 30.8 & 11.6 & 78.6 \\
\hline $\begin{array}{l}\text { Sod } \\
\text { ium } \\
\text { hyd } \\
\text { roxi } \\
\text { de }\end{array}$ & 435 & 82.5 & $\begin{array}{r}0.091 \\
2\end{array}$ & 16.7 & 5.94 & 33.6 \\
\hline $\begin{array}{l}\text { Wat } \\
\text { er }\end{array}$ & 0.118 & $\begin{array}{r}0.009 \\
21\end{array}$ & $\begin{array}{r}0.000 \\
0111\end{array}$ & 0.00236 & $\begin{array}{r}0.0005 \\
16\end{array}$ & $\begin{array}{r}0.00 \\
563\end{array}$ \\
\hline $\begin{array}{l}\text { Elec } \\
\text { trici } \\
\text { ty }\end{array}$ & 2770 & 15.6 & $\begin{array}{r}0.026 \\
3\end{array}$ & 4.33 & 6.93 & 260 \\
\hline Ein & $\begin{array}{r}2494 \\
2\end{array}$ & & & & & \\
\hline
\end{tabular}

In Table $5 \mathrm{~B}$, the results of energy input calculations on the production process unit of palm oil, using of electricity has the largest value of energy input, namely in the un-renewable fossil energy category of $1040 \mathrm{MJ}$. This is caused by the production of electricity using large amounts of un-renewable fossil energy sources. 
This energy of input value is greater than energy of input calculated in the study [9] and [17]. The value of input energy using electricity in research [9] and [17] in the palm oil production process unit is $720 \mathrm{MJ}$ and $990 \mathrm{MJ}$. This energy of input value is smaller than energy of input calculated in the study [14], [15], [16], and [18]. The value of input energy using the electricity in research [14], [15], [16], and [18] is $6090 \mathrm{MJ}, 1510 \mathrm{MJ}$, $1320 \mathrm{MJ}$, and $1410 \mathrm{MJ}$.

The total input energy is the total input energy using diesel, water, and electricity is $1380 \mathrm{MJ}$. The total input energy is greater than the total energy input in research [9], [13], [16], and [17]. The total value of input energy in the study [9], [13], [16] and [17] is $720 \mathrm{MJ}, 280 \mathrm{MJ}$, $1320 \mathrm{MJ}, 1330 \mathrm{MJ}$. The total input energy is smaller than the total energy input in research [14], [15], and [18]. The total value of input energy in the study [14], [15], and [18] is $6630 \mathrm{MJ}, 2410 \mathrm{MJ}$, and $1410 \mathrm{MJ}$.

In table $5 \mathrm{C}$, the results of energy input calculations on the biodiesel production process unit, the use of methanol has the largest value of energy input, namely in the un-renewable fossil energy category of $21000 \mathrm{MJ}$. This is caused by the production of methanol using large amounts of un-renewable fossil energy sources. This energy of input value is greater than energy of input calculated in the study [13], [14], [15], [16], [17], and [18]. The value of input energy using methanol in research [13], [14], [15], [16], [17], and [18] in the biodiesel production process unit is $4899 \mathrm{MJ}, 13370 \mathrm{MJ}$, $14900 \mathrm{MJ}, 13820 \mathrm{MJ}, 70 \mathrm{MJ}$, and $14290 \mathrm{MJ}$. This energy of input value is smaller than energy of input calculated in the study [9]. The value of input energy using the methanol in research [9] is $28030 \mathrm{MJ}$.

The total input energy is the total input energy using methanol, sodium hydroxide, water, and electricity are 24942 MJ. The total input energy is greater than the total energy input in research [13] [14], [15], [16], [17], and [18]. The total value of input energy in the study [13] [14] [15] [16], [17], and [18] is $8110 \mathrm{MJ} 13840 \mathrm{MJ}$ 18060 MJ 1675 MJ 5450 MJ 17320 MJ. The total input energy is smaller than the total energy input in research [9] and [19]. The total value of input energy in the study [9] and [19] is $36060 \mathrm{MJ}$ and $27380 \mathrm{MJ}$.

The total input energy of production of palm biodiesel is the total amount of input energy in the processing unit of plantation of palm, production of palm oil, and production of biodiesel. Total input energy for production of palm biodiesel is 34329 MJ. The biggest contribution of input energy for production of palm biodiesel is due to using of urea as N-fertilizer, electricity, and methanol. Similar results were also found in the study $[9,13,14,15,16,17,18]$.

\subsection{Production of Palm Biodiesel Energy alance}

Analysis of energy balance is to calculate the value of NEB and NER. NEB is calculated utilizing Eout minus Ein. NER is calculated utilizing Eout divided by Ein $[6,7,8]$. Eout 1 ton biodiesel from palm oil is $40200 \mathrm{MJ}$ [20]. Ein 1 ton palm biodiesel is 34329 MJ. Eout (Output Energy), Ein (Input Energy).

$\mathrm{NEB}=$ Eout - Ein
$=$ Eout 1 ton Palm Biodiesel - Ein 1 ton Palm Biodiesel

$=40200 \mathrm{MJ}-34329 \mathrm{MJ}$

$=5871 \mathrm{MJ}$

$\mathrm{NER}=$ Eout $/$ Ein

= Eout 1 ton Palm Biodiesel / Ein 1 ton Palm

Biodiesel

$=40200 \mathrm{MJ} / 34329 \mathrm{MJ}$

$=1.17$

This NEB value is smaller than the NEB value in the study $[14,21,22]$ is $55510 \mathrm{MJ}, 150000 \mathrm{MJ} 27196 \mathrm{MJ}$. This NER value is smaller than the NER value in the study $[14,15,16,17,18,19,22]$ is $2.42,4.99,4.68$, $6.69,4.05,4.58$, and 3.19. This NER value is greater than the NER value in the study [21] is 1.041 .

NEB and NER are positive, meaning that biodiesel production in Banyuasin - Indonesia is feasible to operate. NEB and NER have a positive value mean that there is an energy surplus that occurs for the process of production. The biodiesel output energy is higher than the input energy of the production process of biodiesel. It is good for the biodiesel production sustainability in Banyuasin - Indonesia [14,21,22].

\section{Conclusion}

The processing unit of plantation of palm, production of palm oil, production of biodiesel has the largest input energy derived from un-renewable fossil energy sources. In the plantation process unit of palm, the biggest energy input is due to using of urea as $\mathrm{N}$-fertilizer. In the production process unit of palm oil, the biggest energy input is due to using of electricity. In the biodiesel production process unit, the biggest energy input is due to using of methanol. Value of NEB and NER are positive, meaning that biodiesel production in Banyuasin - Indonesia is feasible to operate. NEB and NER have a positive value means that there is an energy surplus that occurs during the production process. It is good for the sustainability of biodiesel production in Banyuasin Indonesia.

The authors would like to express their gratitude for providing funding for this research through the Masters Program to Doctorate for Bachelor Degree (PMDSU) scholarship by the Directorate General of Science, Technology and Higher Education Resources - the Ministry of Research, Technology, and Higher Education.

\section{References}

1. A. Budiman, R.D. Kusumaningtyas, Y.S. Pradana, N.A. Lestari, Biodiesel : Bahan Baku, Proses dan Teknologi, (Yogyakarta, Gadjah Mada University Press, 2017)

2. ISO 14040, Environmental management - Life cycle assessment - Principles and framework, (Switzerland : ISO, 2006)

3. S. Pleanjai, S.H. Gheewala, S. Garivait, Sustainable Energy and Environment (SEE), 21, 604-608 (2004) 
4. S. Hasibuan, and H. Thaheer, Seminar Nasional Inovasi Dan Aplikasi Teknologi Di Industri, 47, 1-7 (2017)

5. K. Siregar, A.H. Tambunan, A.K. Irwanto, S.S. Wirawan, T. Araki, Energy Procedia , 65, 170 - 179 (2015)

6. H. Shapouri, M. Wang, J.A. Duffield, Renewablesbased technology: sustainability assessment, (England, John Wiley \& Sons Ltd. 2006)

7. K. Prueksakorn, S.H. Gheewala, P. Malakul, Energy for Sustainable Development, 14, 1-5 (2010)

8. T.L.T Nguyen, S.H. Gheewala, S. Garivait, Environ Sci Technol, 41, 4135 - 4142 (2007)

9. S.S. Harsono, A. Prochnow, P. Grundmann, A. Hansen, and C. Hallmann, GCB Bioenergy, 4, 213228 (2012)

10. K. Siregar, Advanced Science Engineering Information Technology, 5, 293-299 (2015)

11. R. Frischknecht, N. Jungbluth, H.J. Althaus, C. Bauer, G. Doka, R. Dones, R. Hischier, S. Hellweg, S. Humbert, T. Köllner, Y. Loerincik, M. Margni, T. Nemecek, Implementation of Life Cycle Impact Assessment Methods. Final report ecoinvent 2000, (Swiss Centre for LCI. Duebendorf, CH, 2003)

12. D.F. Soraya, S.H. Gheewala, S. Bonnet, C. Tongurai, Journal of Sustainable Energy \& Environment, 5, 27-32 (2014)
13. H. Kamahara, U. Hasanudin, A. Widiyanto, R.Tachibana, Y. Atsuta, N. Goto, H. Daimon, K. Fujie, Biomass and Bioenergy, 34, 1818-1824 (2010)

14. S. Pleanjai and S.H. Gheewala, Applied Energy, 86, 209-214 (2009)

15. S.P. Souza, S. Pacca, M.T. Ávila, J.L.B. Borges, Renewable Energy, 35, 2552-2561 (2010)

16. B.J. Wood and R.H. Corley, PORIM intl. palm oil conference e agriculture (1991)

17. K.F. Yee, K.T. Tan, A.Z. Abdullah, K.T Lee, Applied Energy, 86, 189-196 (2009)

18. S. Yusoff and S.B. Hansen, International Journal of Life Cycle Assessment, 12, 50-58, (2007)

19. E.E. Angarita, E.E. Lora, R.E. Costa, E.A. Torres, Renewable Energy, 34, 2905-2913 (2009)

20. S. Papong, T.C.-In, S. Noksa-nga, P. Malakul, Energy Policy, 38, 226-233 (2010)

21. K. Siregar, A.H. Tambunan, A.K. Irwanto, S.S. Wirawan, and T. Araki, International Conference on Sustainable Rural Development (ICRSD): Sustainable Rural Development - Towards a Better World (2013)

22. J.P. Susanto, A.D. Santoso, D.N. Suwedi, Jurnal Teknologi Lingkungan, 18, 165-172 (2017) 